YAK 616.831-005.1-036.11-089

\title{
КОПОЛОВЕЦЬ І.І.
}

КАініка судинної хірургї̈, СхіАно-Словацький інститут серцево-судинних хвороб «VÚSCH», Університет П.Й. Шафарика, меАичний факультет, м. Кошице, Словаччина Ужгородський національний університет, меАичний факультет, кафеАра хірургічних хвороб, м. УжгороА, Україна

\section{ВИБIР ТЕРМIНУ КАРОТИАНОÏ ЕНААРТЕРЕКТОМIÏ У ХВОРИХ ІЗ СИМПТОМАТИЧНИМ СТЕНОЗОМ BHУTPIШHЬOÏ COHHOÏ APTEPIÏ}

\begin{abstract}
Резюме. Проаналізовано результати каротиАної енАартеректомії в 239 хворих із симптоматичним стенозом внутрішньої сонної артерії. У 1-й групі каротидна ендартеректомія була виконана в 68 паціентів (28,5\%) в гострому періоді - Ао 14 Анів віА моменту виникнення інсульту; у 2-й групі-у 171 хворого (71,5\%) — після 14 Анів із моменту порушення кровообігу головного мозку. При порівнянні показників ускАаАнення в ранньому післяопераційному періоді статистична вірогіАність не була виявлена. Часовий інтервал каротиАної енАартеректомії Ао 14 Анів віА розвитку гострого порушення кровообігу головного мозку є виправАаним і безпечним терміном вибору артеріальної реконструкції у пацієнтів із наявністю ішемічного вогнища головного мозку розміром Ао $2 \times 3$ см та при ^егкій неврологічній симптоматиці. Розвиток повторного інсульту в пацієнтів із симптоматичним стенозом сонних артерій, у яких каротиАна енАартеректомія виконана в гострому періоді, становив 2,9\%.

КАючові слова: каротиАна енАартеректомія, інсульт, атеросклероз, стеноз сонних артерій.
\end{abstract}

\section{Вступ}

Однією з найактуальніших проблем сучасної медицини є профілактика та лікування гострих ішемічних порушень мозкового кровообігу (ГІПМК). Розвиток ішемічного інсульту в пацієнтів із стенозом сонних артерій є провідною причиною смертності та інвалідності в системі серцево-судинних захворювань [1]. Окрім того, річний розвиток повторного ішемічного інсульту становить близько $37 \%$, а вірогідність виникнення повторного інсульту протягом 14 днів дорівнює $20 \%$ [2, 3]. За даними рандомізованих досліджень, каротидна ендартеректомія (KЕА) є ефективним методом хірургічної профілактики ГІПМК, а рівень післяопераційних ускладнень у пацієнтів із симптоматичним стенозом внутрішньої сонної артеpiï (ВСА) після КЕА становить до 6 \% [3, 4]. Однак вибір терміну операції після гострого порушення кровообігу головного мозку в пацієнтів із симптоматичним стенозом ВСА залишається й надалі предметом обговорення. У зв'язку з високим ризиком геморагічного розм'якшення після інсульту раніше рекомендували виконувати КЕА в інтервалі 4-6 тижнів після ГІПМК $[1,5]$. Але поступово появились праці, в яких не відмічалось збільшення відсотків інсульту при КЕА протягом 14 днів після інсульту, порівняно з тими, хто відкладав оперативне втручання до 4-6 тижнів [3, 6]. У той же час залишаються відкритими питання: за якими критеріями визначати оптимальний часовий інтервал для КЕА? Що є ризиковим фактором розвитку повторного інсульту?

У своїй роботі ми проаналізували результати КЕА залежно від часового інтервалу після ГІПМК у пацієнтів із симптоматичним стенозом ВСА.

Мета роботи: вивчити результати виконання КЕА в гострому періоді ішемічного інсульту.

\section{Матеріал і методи}

Проаналізовано результати КЕА протягом 6 років у 239 хворих із симптоматичним стенозом ВСА. Вік хворих становив від 36 до 82 років, середній вік пацієнтів $-62,4 \pm 3,5$ року. Серед них чоловіків було 143 $(59,8 \%)$, жінок - $96(40,2 \%)$.

Відповідно хворі розподілені на 2 групи:

1 -ша група - 68 пацієнтів $(28,5 \%)$ : KЕА в гострому періоді до 14 днів після ГІПМК;

2-га група - 171 хворий $(71,5 \%)$ : КЕА після 14 днів до ГІПМК.

За віковими та статевими характеристиками пацієнти в групах не відрізнялись.

Адреса для листування з автором:

Кополовець Іван Іванович

E-mail: i.kopolovets@gmail.com

(с) Кополовець I.І., 2016

(c) «Український журнал хірургії», 2016

(C) Заславський О.Ю., 2016 
У 1-й групі КЕА протягом 72 годин виконано п'ятьом особам (2,1 \%); у період від 3 до 14 днів від моменту виникнення інсульту КЕА проведено 63 особам (26,4 \%).

У 2-й групі KEA була виконана після 6 тижнів від моменту розвитку ГІПМК.

Вибір часового інтервалу для виконання КЕА (табл. 1) формувався за таким алгоритмом: усім хворим із симптоматичним стенозом ВСА виконували комп'ютерну томографію головного мозку з метою виявлення ішемічних вогнищ. За наявності ішемічного вогнища головного мозку розміром до $2 \times 3$ см та при мінімальній неврологічній симптоматиці KЕА рекомендували виконувати протягом перших 14 днів після інсульту. У випадку виявлення ішемічного вогнища понад $2 \times 3$ см або декількох вогнищ КЕА виконували після 5-6 тижнів із моменту перенесеного гострого ішемічного порушення кровообігу головного мозку.

KEA проводили під загальним знеболюванням із інтраопераційним нейромоніторингом за допомогою церебральної оксиметрії. Для виконання КЕА використовували дві методики: у 118 пацієнтів (49,4 \%) класичну ендартеректомію 3 подальшою пластикою за допомогою синтетичної заплати; у 87 пацієнтів (36,4 \%) - еверсійну ендартеректомію. У випадку зниження сатурації головного мозку понад 25-30\% від вхідного показника під час артеріальної реконструкції використовували у 11,5 \% хворих інтраопераційний шунт. При використанні інтраопераційного шунта КЕА виконували за класичною методикою.

Кожний пацієнт в ранньому післяопераційному періоді спостерігався в палаті інтенсивної терапії.

Статистична обробка виконувалась у програмі Microsoft Excel-2013. Усі результати наведені в таблицях у вигляді кількісних характеристик та процентного співвідношення. Вірогідність отриманих результатів у групах оцінювали за допомогою Mann - Whitney nonparametric test (SPSS 22.0.).

Таблиця 1. Часовий інтервал виконання каро-
тидної ендартеректомії від моменту розвитку
ішемічного інсульту
\begin{tabular}{|c|l|c|c|}
\hline \multirow{2}{*}{$\begin{array}{c}\text { Гру- } \\
\text { пи }\end{array}$} & $\begin{array}{c}\text { Часовий інтервал } \\
\text { виконання КЕА }\end{array}$ & $\begin{array}{c}\text { Пацієнти, яким } \\
\text { проведено КЕА } \\
\text { (n= 239) }\end{array}$ & $\%$ \\
\hline \multirow{3}{*}{ 1-ша } & До 3-6 годин & 1 & 0,4 \\
\cline { 2 - 4 } & До 24-72 годин & 4 & 1,7 \\
\cline { 2 - 4 } & Від 3-го до 14-го дня & 63 & 26,4 \\
\hline \multirow{2}{*}{ 2-га } & Після 5-6 тижнів & 171 & 71,5 \\
\hline
\end{tabular}

Примітка: КЕА - каротидна ендартеректомія.

\section{Результати}

За результатами табл. 2, у 1-й групі (68 пацієнтів; ранній післяопераційний період) ГІПМК розвинулось у двох пацієнтів (2,9\%); в одного пацієнта виник інфаркт міокарда $(1,5 \%)$; помер один пацієнт (1,5\%). У 2-й групі (171 пацієнт; ранній післяопераційний період) ГІПМК розвинулось у шести пацієнтів (3,5\%); в одного пацієнта виник інфаркт міокарда $(0,6 \%)$; померли 2 пацієнти (1,2\%).
Таблиця 2. Великі ускладнення в ранньому післяопераційному періоді, n (\%)

\begin{tabular}{|l|c|c|c|}
\hline $\begin{array}{c}\text { Усклад- } \\
\text { нення }\end{array}$ & $\begin{array}{c}\text { 1-ша гру- } \\
\text { па (n=68) }\end{array}$ & $\begin{array}{c}\text { 2-га група } \\
\text { (n= 171) }\end{array}$ & $\mathbf{P}$ \\
\hline ГІПМК & $2(2,9)$ & $6(3,5)$ & $<0,05$ \\
\hline IM & $1(1,5)$ & $1(0,6)$ & $<0,05$ \\
\hline Смертність & $1(1,5)$ & $2(1,2)$ & $<0,05$ \\
\hline
\end{tabular}

\section{Примітка: IM - інфаркт міокарда.}

При порівнянні результатів післяопераційних ускладнень статистичної відмінності не виявлено $(\mathrm{p}<0,05)$.

\section{Обговорення}

Гострий церебральний інсульт розглядається в цей час як критичний стан, що потребує екстренної комплексної медичної допомоги [4, 7]. Вторинна профілактика ГІПМК повинна розпочинатися якнайшвидше після розвитку першого інсульту або транзиторної ішемічної атаки (ТІА) [5, 7]. КЕА, як хірургічна профілактика ГІПМК, дозволяє практично на $40 \%$ знизити розвиток повторного інсульту в пацієнтів із симптоматичним стенозом ВСА [6]. Доцільність ранніх реконструкцій ВСА обумовлена тим, що протягом 14 днів зберігається найбільш високий ризик розвитку повторного ГІПМК [2]. Аналізуючи результати нашого дослідження, слід відзначити, що показники післяопераційних ускладнень у симптоматичних пацієнтів, яким KЕА виконувалась до 14 днів, статистично не були вірогідними порівняно з групою пацієнтів, яким КЕА виконувалась через 5-6 тижнів після ГІПМК. Наші результати відповідають результатам інших публікацій, де також вказують на наявність низьких показників післяопераційних ускладнень у випадку виконання КЕА в гострому періоді [5, 7]. Слід відзначити, що рівень ускладнень не залежав від вибору методики KЕА [3, 8]. Ключову роль у боротьбі з розвитком післяопераційних ускладнень відіграє комплексний відбір пацієнтів для KЕА з урахуванням неврологічного та соматичного статусу, розміру ішемічного вогнища головного мозку та мультифокальності атеросклерозу [2, 7]. Надзвичайно важливу роль відіграє техніка КЕА та досвід судинного центру у виконанні артеріальних реконструкцій на сонних артеріях [3, 5].

Сьогодні ми впроваджуємо новий алгоритм диференційного відбору пацієнтів для KЕА в гострому періоді, згідно з яким розроблені показання для КЕА до 6 годин та 3 діб від моменту розвитку ГІПМК. У даному випадку ми враховуємо високу вірогідність розвитку повторного ішемічного інсульту в пацієнтів із нестабільною неврологічною симптоматикою та морфологічно нестабільною атеросклеротичною бляшкою. Тому КЕА до 72 год рекомендуємо пацієнтам з хоча б одним із таких критеріїв:

- м'яка високоембологенна атеросклеротична бляшка;

- атеросклеротична бляшка з елементами виразкування;

- розшарування атеросклеротичної бляшки;

- атероматозна атеросклеротична бляшка;

- субтотальний стеноз ВСА. 
Пацієнтам із нестабільною неврологічною симптоматикою (повторні TIA, crescendo TIA, stroke in evolution), в яких джерелом емболізації є басейн сонної артерії зі стенозом понад $50 \%$, а тромболізисна терапія протипоказана, КЕА рекомендуємо виконувати до 6 год від моменту розвитку ГІПМК.

\section{Висновки}

1. Часовий інтервал КЕА до 14 днів від розвитку гострого порушення кровообігу головного мозку є виправданим і безпечним терміном вибору артеріальної реконструкції в пацієнтів із наявністю ішемічного вогнища головного мозку розміром до $2 \times 3$ см і при легкій неврологічній симптоматиці.

2. Розвиток повторного інсульту в пацієнтів із симптоматичним стенозом сонних артерій, в яких КЕА виконана в гострому періоді, становив 2,9\%.

\section{Список Аітератури}

1. Выбор оптимального метода лечения атеросклеротических стенозов внечерепных отделов сонных артерий / E.I. Levy, J. Mocco, R.M. Samuelson [et al.]// Практична ангіологія. - 2010. - Вип. 31, № 2. - C. 28-31.

2. Каротидная эндартерэктомия у больных с высоким хирургическим риском / А.Д. Ахмедов, Д.Ю. Усачев,
В.А. Лукшин [и др.] // Вопросы нейрохирургии. 2013. - № 77(4). - C. 36-41.

3. Оценка отдаленных результатов нового способа эверсионной каротидной эндартерэктомии / А.В. Яриков, В.Л. Сергеев, А.С. Мухин // Современные проблемы науки и образования. - 2015. - № 6.

4. Родін Ю.В. Деякі міркування судинного хірурга з приводу операцій на сонних артеріях / Ю.В. Родін // Науковий вісник Ужсгородського університету, серія «Медицина» - 2012. - № 2(44). - С. 97-101.

5. Синдром обкрадання при патології судин дуги аорти / B.I. Русин, В.В. Корсак, С.С. Буцко [та ін.]. - Уэкгород: Карпати, 2011. - 208 c.

6. Carotid endarterectomy: are we meeting the teo week target? / R.V. Guest, J.M. Richards, S.C. Fraser, R.T Chalmers // Scott. Med. J. - 2009. - Vol. 54. - P. 27-29.

7. Early carotid endarterectomy after intravenou thrombolysis for acute ischemic stroke / M.A. Bartoli, C. Squarncioni, F. Nicoli [et al.]// Eur. J. Vasc. Endavasc. Surg. 2009. - № 37. - P. 512-518.

8. Naylor A.R. There is more to preventing stroke after carotid surgery than shunt and patch debate / A.R. Naylor // J. Vasc. Endovasc. Surg. - 2005. - Vol. 4. - P. 329-333.

Отримано 08.05.16

\section{Кополовец И.И.}

КАиника сосуАистой хирургии, Восточно-САовацкий институт серАечно-СосуАистых заболеваний “VÚSCH», Университет П.И. Шафарика, меАицинский факультет, г. Кошице, Словацкая Республика ВГУЗ «Ужгородский национальный университет», меАицинский факультет, г. УжгороА, Украина

\section{ВЫБОР СРОКА КАРОТИАНОЙ ЭНААРТЕРЭКТОМИИ У БОАЬНЫХ С СИМПТОМАТИЧЕСКИМ СТЕНОЗОМ ВНУТРЕННЕЙ СОННОЙ АРТЕРИИ}

Резюме. Проанализированы результаты каротидной эндартерэктомии у 239 больных с симптоматическим стенозом внутренней сонной артерии. В 1-й группе каротидная эндартерэктомия была проведена у 68 пациентов $(28,5 \%)$ в остром периоде - до 14 дней с момента возникновения инсульта; во 2-й группе - у 171 больного (71,5 \%) - после 14 дней с момента нарушения кровообращения головного мозга. При сравнении показателей осложнения в раннем послеоперационном периоде статистическая достоверность не была выявлена. Временной интервал каротидной эндартерэктомии до 14 дней с момента развития острого нарушения кровообращения головного мозга является оправданным и безопасным сроком выбора артериальной реконструкции у пациентов с ишемическим очагом головного мозга размером до $2 \times 3$ см и легкой неврологической симптоматикой. Развитие повторного инсульта у пациентов с симптоматическим стенозом сонных артерий, у которых каротидная эндартерэктомия проводилась в остром периоде, составляло $2,9 \%$.

Ключевые слова: каротидная эндартерэктомия, инсульт, атеросклероз, стеноз сонных артерий.

\section{Kopolovets I.I.}

Clinic of Vascular Surgery, East Slovak Institute of Cardiovascular Diseases "VúSCH», Pavol Jozef Šafárik University, Faculty of

Medicine, Košice, Slovak Republic

Uzhhorod National University, Medical Faculty, Uzhhorod, Ukraine

\section{SELECTION OF THE DATE FOR PERFORMANCE OF CAROTID ENDARTERECTOMY IN PATIENTS WITH SYMPTOMATIC STENOSIS OF THE INTERNAL CAROTID ARTERY}

Summary. The results of carotid endarterectomy were analyzed in 239 patients with symptomatic internal carotid artery stenosis. In group 1, $68(28.5 \%)$ patients underwent carotid endarterectomy in the acute period - within 14 days after stroke onset, in group $2-$ $171(71.5 \%)$ patients - 14 days after the cerebrovascular accident. When comparing complication parameters in the early postoperative period, there was observed no statistical probability. A time interval of $<14$ days between the onset of acute cerebrovascular disease and carotid endarterectomy is reasonable and safe period for arterial reconstruction in patients with ischemic focus of the brain up to $2 \times 3 \mathrm{~cm}$ in size and mild neurological symptoms. The incidence of recurrent stroke in patients with symptomatic carotid stenosis, in whom a carotid endarterectomy has been performed in the acute period, amounted to $2.9 \%$.

Key words: carotid endarterectomy, stroke, atherosclerosis, carotid artery stenosis. 